\title{
Social emancipation and occupational therapy: approaches from Epistemologies of the South and the Ecology of Knowledges
}

\section{Emancipaçâo social e terapia ocupacional: aproximaçóes a partir das Epistemologias do Sul e da Ecologia de Saberes ${ }^{1}$}

Isabela Aparecida de Oliveira Lussia ${ }^{a}$ (D)

${ }^{a}$ Universidade Federal de São Carlos - UFSCar, São Carlos, SP, Brasil.

How to cite: Lussi, I. A. O. (2020). Social emancipation and occupational therapy: approaches from Epistemologies of the South and the Ecology of Knowledges. Cadernos Brasileiros de Terapia Ocupacional. 28(4), 1335-1345. https://doi.org/10.4322/2526-8910.ctoEN2015

\begin{abstract}
$\underline{\text { Abstract }}$
This essay brings a theoretical thought on the phenomenon of social emancipation and Occupational Therapy, based on the theories developed by Boaventura de Sousa Santos, specifically the Epistemologies of the South, and the Ecology of Knowledge. It relies on the sociology of absences, and on the concept of abyssal thinking, to reflect on the misuse of the experience of the people who benefit from Occupational Therapy, examining three modes of non-existence production: the one resulting of the logic of monoculture of knowledge and rigor of knowledge, the one related to the logic of social classification, and the one based on the productivist logic. It presents the ecologies as a way to overcome the absences, particularly the ecology of knowledge, the ecology of recognition, and the ecology of productivity, discussing the possibilities inside Occupational Therapy. It points out the sociology of emergencies and translation work as possible ways for social emancipation, and the implications of cosmopolitan rationality for Occupational Therapy.
\end{abstract}

Keywords: Occupational Therapy, Knowledge, Social Marginalization, Social Vulnerability.

\section{Resumo}

Este ensaio traz uma reflexão teórica sobre o fenômeno da emancipação social e a terapia ocupacional, fundamentada nas teorias desenvolvidas por Boaventura de Sousa Santos, particularmente, as Epistemologias do Sul e a Ecologia de Saberes. Apoia-se na sociologia das ausências e no conceito do pensamento abissal para

${ }^{1}$ This essay comes from the author's studies during the Post-Doctoral Internship at the Center for Social Studies at the University of Coimbra, Portugal, from April to October/2016, under the supervision of Professor Boaventura de Sousa Santos. 
refletir sobre o desperdício da experiência das próprias pessoas que se beneficiam da terapia ocupacional, discutindo três modos de produção da não-existência: o que deriva da lógica da monocultura do saber e do rigor do saber; aquele relacionado à lógica da classificação social; e o que se apoia na lógica produtivista. Apresenta as ecologias como forma de superação das ausências, mais especificamente, a ecologia de saberes, a ecologia dos reconhecimentos e a ecologia das produtividades, discutindo as possibilidades na terapia ocupacional. Aponta a sociologia das emergências e o trabalho de tradução como caminhos possíveis para a emancipaçấo social e as implicaçôes da racionalidade cosmopolita para a terapia ocupacional.

Palavras-chave: Terapia Ocupacional, Conhecimento, Marginalização Social, Vulnerabilidade Social.

\section{Knowledge and Social Emancipation}

To discuss the phenomenon of social emancipation, correlating it with occupational therapy, I will be based on the contributions of Boaventura de Sousa Santos, especially on the theoretical reflections on Southern Epistemologies and the Ecology of Knowledge.

To this end, I will start with his questions about modern science in which sustained by capitalism, colonialism, and patriarchy wasted the knowledge produced in subordinate contexts, from practice and experience.

We need to mention the concept of abyssal thinking developed by Santos (2009), which " $[. .$.$] operates by the unilateral definition of lines that divide experiences,$ knowledge and social actors between those that are useful, intelligible and visible" (those that remain side of the line, or in the North) "[...] and those that are useless or dangerous, unintelligible, objects of suppression or forgetfulness" (those that are on the other side of the line, or in the South) (Santos \& Meneses, 2009, p. 13). The abyssal line is a metaphor used to explain the radical division of social reality between North and South (between hemispheres, on continents, in countries, etc.).

Thus, I argue that this is the first reflection for occupational therapy, especially for occupational therapy in the countries of the South since it developed through practice with marginalized, excluded, invisible, and distant people from the social emancipation processes. I believe that a theory that breaks with the processes of exclusion and articulates with social emancipation can contribute greatly to occupational therapy in the South.

Boaventura de Sousa Santos does not show a unique concept of social emancipation but develops theories that focus on its processes, above all, it explores social emancipation in emancipatory practices.

The understanding of social emancipation starts from the logic of regulation/emancipation on which metropolitan societies were structured in opposition to the logic of appropriation/violence that prevailed in colonial territories (Santos, 2009), and the very tension between social regulation and social emancipation in a Liberal State (Santos, 2003). The author analyzes in-depth the social processes that 
occurred in modernity, pointing out that although it was in this period that equality, freedom, and citizenship were recognized as emancipatory principles of social life. From the development of capitalism, societies have passed living from the contradiction between the principles of emancipation, which focused on equality and social integration, and the principles of regulation, which managed the processes of inequality and exclusion (Santos, 1999). We can observe that the author starts from the idea of social emancipation related to the achievement of rights and equality.

He assumes that social emancipation exists, but it needs to be reinvented. This is only possible because in modern society there is a tension between people's experiences, which are often bad, and the expectations of a better life and society. This is a new question, "[...] since, in ancient societies, experiences coincided with expectations: those who were born poor, died poor; whoever was born illiterate, died illiterate" (Santos, 2007, p. 18).

The author argues that this discrepancy between experiences and expectations is fundamental for understanding how he and his group of researchers think about social emancipation in modern society. Thus, he proposes theories that focus on this tension between experiences and expectations, which I will explain throughout the text.

The author argues that emancipation must be built "[...] from a new relationship between respect for equality and the principle of recognition of difference", since the whole theory about emancipation was guided by the principle of equality, without even touching on the recognition of differences.

Now we have to try a theoretical construction in which the two are present and to know that a fight for equality must also be a fight for the recognition of difference because the important thing is not homogenization but the same differences (Santos, 2007, p. 62-63).

This issue will be further explored in the text.

Finally, the reinvention of social emancipation is linked to a series of elements related to the processes of visibility and production of the existence of marginalized groups, who experience situations of social exclusion and deprivation of citizenship rights.

I will briefly show the concepts of metonymic reason and proleptic reason - two of the ways that Santos (2010) calls indolent reason - to go through the criticism elaborated by the author on this rationality and arrive at the rationality developed by him called cosmopolitan reason, based on the Sociology of Absences, the Sociology of Emergencies and the Work of Translation.

When questioning hegemonic western knowledge, Santos $(2000,2010)$ states that profound structural changes in knowledge require changes in the "[...] reason that presides over both knowledge and their structuring, that is, it is necessary to challenge indolent reason" (Santos, 2010, p. 97). Thus, he elaborates on the critique of indolent reason based on two of its forms: metonymic reason and proletatic reason, and proposes cosmopolitan reason, founded on the sociology of absences, the sociology of emergencies, and the work of translation. This form of rationality is committed to social emancipation.

In short, the metonymic reason is based on the idea of totality. All knowledge and all action are related to the whole and the whole is sovereign to each of its parts. As a 
consequence of this way of understanding the world, we have the exclusivity of the western understanding of the world and the impossibility of thinking the parts outside the relationship with the totality. Thus, knowledge based on this limited view of the world wasted a lot of social experience on it (Santos, 2010).

The proleptic reason is based on the idea of the concept of "[...] the future from the monoculture of linear time" (Santos, 2010, p. 115). This conception leads us to know the future history in the present, placing the future as infinite (Santos, 2007).

According to Santos (2010), the recovery of the wasted experience is possible through the critique of metonymic reasons. Thus, we need to expand the world by expanding and diversifying the present ${ }^{2}$. The author argues that this process must begin with what he calls the sociology of absences.

It is an investigation that aims to demonstrate that what does not exist is actively produced as non-existent, that is, as a non-credible alternative to what exists. Its empirical object is considered impossible based on the conventional social sciences, so its simple formulation already represents a break with them. The objective of the sociology of absences is to transform impossible objects into possible ones and based on them, transform absences into presences (Santos, 2010, p. 102).

The author states that "There is a production of non-existence whenever a given entity is disqualified and made invisible, unintelligible or irreversibly disposable" (Santos, 2010, p. 102). It identifies five modes of production of non-existence: the first is from the monoculture of knowledge and the rigor of knowledge and produces the social form of the non-existence of the ignorant; the second is based on the monoculture of linear time and produces the residual; the third refers to the logic of social classification producing the inferior; the fourth is based on the logic of the dominant scale and produces the place; and, finally, the fifth refers to the productivist logic and relies on the monoculture of the capitalist productivity criteria producing the unproductive $^{3}$ (Santos, 2010).

The most powerful way of the non-existence production is that one supported by the logic of the monoculture of knowledge and the rigor of knowledge since it is supported by the argument that modern science and high culture are "[...] exclusive canons for the production of knowledge or artistic creation", respectively (Santos, 2010, p. 103). Thus, any knowledge beyond what is valid in modern science is not recognized as knowledge.

I have a question but I will discuss it later in the text. To what extent has occupational therapy considered the knowledge of the people who benefit from it, whether in a situation of professional practice or research? To what extent is the knowledge developed by the different occupational therapies existing in the world reciprocally recognized?

The sociology of absences proposes to free the experiences produced as absent from the relationships that produced them as such and become present, that is, "[...] to consider alternatives to hegemonic experiences, their credibility can be discussed and

\footnotetext{
${ }^{2}$ For an understanding of Santos' theory of expanding the present and contracting the future, see Santos (2010).

${ }^{3}$ For details on the five non-existence ways of production, see Santos (2010).
} 
argued and their relationships with hegemonic experiences may be the subject of political dispute" (Santos, 2010, p. 104-105).

\section{Ecologies as a Way to Overcome Absences}

Santos (2010) shows that the liberation of the experiences produced as absent from the relationships that produced them as such is done through the questioning of how such as excluding the concept of totality has remained so hegemonic in the last two hundred years and by identifying the modes of confrontation and overcoming this conception of wholeness and the metonymic reason that sustains it. The second form is highlighted and pointing out that such overcoming is possible by questioning each of the forms of absence production described by him. To this end, it proposes replacing monocultures with ecologies, in the sense of "[...] recognizing the plurality of heterogeneous knowledge (one of which is modern science) and in sustainable and dynamic interactions between them without compromising their autonomy" (Santos, 2009, p. 44-45).

There are five identified ecologies: the ecology of knowledge, the ecology of temporalities, the ecology of recognitions, the ecology of trans-scales, and the ecology of productivities (Santos, 2010).

I will talk about three of them: the ecology of knowledge, the ecology of recognitions, and the ecology of productivities discussing the possibilities in the occupational therapy area.

The ecology of knowledge starts from "[...] the identification of other knowledge and other criteria of rigor that operate credibly in social practices [...] The central idea of the sociology of absences in this domain is that there is no ignorance in general or knowledge in general" (Santos, 2010, p. 106). It starts from the assumption that all relationships between human beings and between them and nature involve more than one form of knowledge and ignorance. This means that scientific knowledge in the ecology of knowledge is not discarded, it is used in a counter-hegemonic way.

On the one hand, it is about exploring alternative scientific practices that have become visible through the pluralistic epistemologies of scientific practices and, on the other hand, promoting interdependence between scientific knowledge, produced by Western modernity, and other, non-scientific knowledge. The principle of the incompleteness of all knowledge is a condition for the possibility of epistemological dialogue and debate between different forms of knowledge (Santos, 2010, p. 107).

As pointed out by Galheigo (2014), since the 1980s, occupational therapy developed in the countries of the South has produced practices and knowledge that go hand in hand with the struggle for social emancipation and the conquest of citizenship rights of historically excluded collectives.

Reflecting on the earlier questioning in this text, I point out that, when working directly with socially excluded people and collectives, occupational therapy will certainly be able to develop social emancipation processes with them, insofar as the practices and knowledge constructed collectively consider the knowledge of everyone involved. 
The ecology of recognitions is a way of confronting the logic of the production of absences in social classification (Santos, 2010). "The coloniality of modern and western capitalist power" identifies differences with inequality and determines "[...] who is equal and who is different" (Santos, 2010, p. 110).

The sociology of absences is confronted with coloniality, looking for a new articulation between the principle of equality and the principle of difference and opening space for the possibility of equal differences - an ecology of differences made of reciprocal recognition (Santos, 2010, p. 110).

For the author, some social movements in Latin America such as the feminist, indigenous, and Afro-descendant movements have sparked the struggle for an ecology of recognition.

The ecology of recognitions aims at the widening of the circle of equal differences (Santos, 2010). In this sense, I highlight in Brazil, the proximity of the Psychiatric Reform and People with Disabilities movements for sharing the ideology and struggle for the rights of excluded people and a more just and solidary society. I understand that this proximity opens space for the identification of equal differences and puts us on the path to the ecology of recognitions, with strong participation of occupational therapists (OT) due to the great involvement in these two movements.

Through this proximity, I also discuss the ecology of productivities. According to Santos (2010), in the field of productivist logic

[...] the sociology of absences consists of the recovery and valorization of alternative production systems, popular economic organizations, workers' cooperatives, self-managed companies, solidarity economy, etc., which the capitalist productivist orthodoxy hid or discredited (Santos, 2010, p. 113).

Occupational therapy is directly related to the work dimension in human life since its creation as a profession. However, in the countries of the South, also since the 1980s, it has been committed both to the production of practices aimed at achieving workers' rights and access to health, as well as the right to work of people who have been aborted from the world of work.

In Brazil, the struggle for the right to work of excluded people found fertile ground in the Solidarity Economy movement, which leads me to choose this alternative system for discussing the ecology of productivity. I also make this choice because of my proximity and experience as an occupational therapist in the mental health area and solidarity economy.

The solidarity economy appears as another form of work organization, an alternative to the characteristic molds of the capitalist system. It is also a movement to change people's way of life, stimulating solidarity, democracy, and respect for others, nature, and differences, enabling the opening of the way to social inclusion through work for people who, in several ways, are in a situation of social exclusion.

The solidarity economy is a concept used in several countries of the world with different meanings. However, always guided by the idea of solidarity in opposition to 
the competitive individualism that marks the economic behavior in capitalist societies (Singer, 2003). The concept of solidarity economy

[...] refers to producer organizations, consumers, savers, etc., which are distinguished by two specificities: (a) they encourage solidarity among members through the practice of self-management and (b) they practice solidarity with the working population in general, with an emphasis on helping the most disadvantaged people (Singer, 2003, p. 116).

Self-management is a set of social practices characterized by democratically making decisions, which enable the autonomy of a collective. "It is an exercise of shared power, which qualifies the social relationships of cooperation between people and/or groups [...] by intentionally expressing more horizontal social relationships" (Albuquerque, 2003, p. 20).

Solidarity economy enterprises prioritize the organization of groups formed by unemployed people for various reasons, such as age, lack of qualification or professional experience, race or gender discrimination, and workers in the process of losing their jobs, for example, which characterizes the specificity of solidarity with the disadvantaged people (Singer, 2003). Also, they are intended for people who are in a socially disadvantaged situation for other reasons, such as people with psychological distress, people with disabilities, people with problematic use of alcohol or other types of drugs, who are discharged from the prison system, among others.

The study by Morato \& Lussi (2015) revealed that the solidarity economy is a reference for the organization of work and the practice of the occupational therapist in initiatives of social inclusion through work. Nine of the ten initiatives participating in the study, in which the twelve occupational therapists interviewed worked, referred to the link with the solidarity economy. The participants also reported

[...] that there is a proposal for a work that is built collectively between professionals and users, and that is translated into shared practices, in exchanges of knowledge, in solidary relationships, in the division of tasks, in the appropriation of all stages of work by the user, in collective decisions and division of tasks by affinity (Morato \& Lussi, 2015, p. 740).

In my perception, this excerpt explains not only the production of occupational therapy practices in the logic of the ecology of productivities but also in the logic of the ecology of knowledge. Thus, I argue that occupational therapy in Brazil has contributed to the process of turning absences into presences.

\section{Sociology of Emergencies: Paths to Social Emancipation}

According to Santos (2010), while the sociology of absences expands the present through the critique of metonymic reason, the sociology of emergencies contracts the future through the criticism of proletatic reason. As previously mentioned, "Proleptic reason is the face of indolent reason when conceiving the future from the monoculture of linear time" (Santos, 2010, p. 115). For the author, 
The sociology of emergencies consists of replacing the void of the future according to linear time (void that is both everything and nothing) with a future of plural and concrete possibilities, both utopian and realistic, that is being built in the present through the activities of care (Santos, 2010, p. 116).

The sociology of emergencies is guided by the concept of Not-Yet, proposed by Ernst Bloch (1995, apud Santos, 2010). The Not-Yet is related to a determined and not infinite future. "It is a concrete possibility and capacity that neither exists in a vacuum, nor are completely determined", on the one hand, it is "[...] capacity (power) and, on the other, possibility (potential)" (Santos, 2010, p. 116-117).

The sociology of emergencies is related to the investigation of alternatives of concrete possibilities, acting "[...] both on the possibilities (potentiality) and on the capacities (power)". It consists of performing "[...] a symbolic expansion of knowledge, practices, and agents", to identify "[...] future trends (the Not-Yet)" possible to "[...] maximize the probability of hope in the probability of frustration" (Santos, 2010, p. 118). This expansion aims to get to know the conditions of the possibility of hope in a more comprehensive way and to define principles of action so that the performance of such conditions is done (Santos, 2010).

Thus, the author points out that the sociology of emergencies operates in the field of possible social expectations, expanding it, while the sociology of absences operates in the field of social experiences already available, expanding it.

The expectations legitimized by the sociology of emergencies are contextual because they are measured by concrete and radical possibilities and capacities, and because, within the scope of these possibilities and capacities, they demand a strong performance that defends them from frustration. These expectations point to new paths for social emancipation, or better, social emancipation (Santos, 2010, p. 119).

In this sense, the sociology of emergencies can help us to identify the paths for the social emancipation of historically excluded people who benefit from occupational therapy practices. That is, since occupational therapy develops practices that contribute to the process of making absences into presences, it also enables the investigation of concrete alternatives of potentialities and powers, particularly, linked to individual and collective human activity.

The sociology of emergencies operates through two procedures. One aims to "[...] make our knowledge of the conditions of the possible less partial" and the other aims to "[...] make the conditions of the less partial" (Santos, 2010, p. 120). These procedures are related to the knowledge of clues or signs of the investigated realities and their strengthening. The knowledge that anchors the sociology of emergencies is argumentative and "[...] advances as it credibly identifies emerging knowledge, or emerging practices” (Santos, 2010, p. 120).

The greater the "[...] multiplicity and diversity of available and possible experiences", the greater the expansion "[...] of the present and the contraction of the future" (Santos, 2010 , p. 120). While in the sociology of absences multiplication and diversification occur through ecologies, the sociology of emergencies reveals them through the 
symbolic amplification of clues or signs, probably in the following social fields: experiences of knowledge, experiences of development, work and production, experiences of recognition, experiences of democracy and experiences of communication and information (Santos, 2010).

For Santos (2010), the task notice the inexhaustible diversity of the world, based on cosmopolitan reason, is not to identify new totalities or "[...] adopt other general meanings for social transformation", but "[...] to propose new ways to think about these totalities and those meanings and new processes of carrying out ethical and political convergences" (Santos, 2010, p. 123). Thus, it proposes translation work as an alternative to the general theory.

The translation is the procedure that allows creating reciprocal intelligibility between the experiences of the world, both available and possible, revealed by the sociology of absences and the sociology of emergencies. It is a procedure that does not attribute to any set of experiences neither the status of exclusive wholeness nor the status of the homogeneous part. The experiences of the world are seen at different times in the translation work as totalities or parts and as realities that are not exhausted in these totalities or parts (Santos, 2010, p. 123-124).

Intercultural translation presupposes that there are different subjectivities, different languages, different forms of access to power between people and society. The translation is done through processes that create spaces for dialogue and spaces of shared power.

In the occupational therapy area in mental health, for example, we can recognize processes of intercultural translation in social inclusion initiatives through work in the solidarity economy, in cultural initiatives, and in processes of participation and social control, in which people who have been deprived participation and voice start to participate actively and have the right to voice. Through the creation of spaces in which these people exercise power, in some way, and spaces of emancipation, a space of cognitive justice is created, in which knowledge hierarchies are dissolved, attenuated, crossing boundaries and abyssal lines.

\section{Implications for Occupational Therapy}

In addition to the approximations between the cosmopolitan rationality proposed by Santos (2010), which is articulated with social emancipation and occupational therapy already described in this text, I describe some implications that I observe of this rationality for occupational therapy.

As already pointed out by Galheigo (2014), studies on Southern Epistemologies help us to identify that there are several occupational therapies produced in the countries of the South, in line with social movements and their struggles for social emancipation and conquest of citizenship rights. The identifications between occupational therapies in the South differentiate us from the identity incorporated at the beginning of the profession from the countries of the North. 
In this sense, I return to the question posed earlier in this text about the existence or not of recognition of the knowledge developed by the different occupational therapies existing in the world and I argue that the North must also learn from the South about occupational therapy.

There is also a relationship with the ecology of recognitions since occupational therapies in the South, specifically in Latin America, developed from equal differences, that is, from the development of actions aimed at marginalized populations, in largely as a result of the colonization processes that were unique in each of the countries of Latin America.

Another implication of Southern Epistemologies and Knowledge Ecology for occupational therapy is the possibility of using social emancipation as a theoreticalanalytical reference in research and knowledge production in occupational therapy. Reflecting on occupational therapy through the lens of social emancipation contributes greatly, in my view, to the episteme of occupational therapy.

Also, in the occupational therapy research area, the choice of emancipatory research (doing research with people and not doing about people) allows both the construction of counter-hegemonic knowledge in occupational therapy, that is, that it also considers the knowledge of all people involved in the investigation. For example people with disabilities, people with psychological distress, people on the street, marginalized children and adolescents, etc., as it contributes to real processes of social emancipation.

Finally, I point out that there may be a great and important relationship between occupational therapy and emancipatory practices, both concerning professional and research practices. Occupational therapy, due to its characteristic of doing together, of doing shared, is a fertile field so that emancipatory practices can be developed together with people, in the perspective of building collectively. In this sense, I argue that the practices developed jointly between the occupational therapist and the person or collectives can be emancipatory insofar as there is not a centrality of these practices in the knowledge and professional training of the OT, but the real needs of the person or collectives and their role in the struggle for a better life and society. In other words, it is not a matter of "giving" the other the possibility but, developing with the other the possibility. I think that this is the basis for the development of emancipatory practices and they can and should take place in any area of occupational therapy.

As stated earlier in this text, the possibility of occupational therapy's contribution to the process of making absences into presences - knowledge, productivity, recognition, etc. - and to investigate the concrete alternatives of powers and potential of people and collectives, can help in the paths towards social emancipation.

\section{References}

Albuquerque, P. P. (2003). Autogestão. In A. D. Cattani (Ed.), A outra economia (pp. 20-26). Porto Alegre: Veraz Editores.

Galheigo, S. M. (2014). Sobre identidades, latinoamericanidades e construçáo de saberes em terapia ocupacional: diálogos com Boaventura de Sousa Santos. Cadernos de Terapia Ocupacional da UFSCar, 22(1), 215-221. http://dx.doi.org/10.4322/cto.2014.023.

Morato, G. G., \& Lussi, I. A. O. (2015). Iniciativas de geração de trabalho e renda, economia solidária e terapia ocupacional: aproximações possíveis e construçôes necessárias. Cadernos de Terapia Ocupacional da UFSCar, 23(4), 733-745. http://dx.doi.org/10.4322/0104-4931.ctoAO0737. 
Santos, B. S. (1999). A construção multicultural da igualdade e da diferença. Oficina do CES. No 135: publicação seriada do centro de estudos sociais. Coimbra: Colégio São Jerónimo. Recuperado em 10 de maio de 2016, de https://www.ces.uc.pt/publicacoes/oficina/135/135.pdf

Santos, B. S. (2000). Crítica da razão indolente: contra o desperdício da experiência. São Paulo: Cortez.

Santos, B. S. (2003). Poderá o direito ser emancipatório? Revista Critica de Ciências Sociais, 65(65), 3-76. http://dx.doi.org/10.4000/rccs. 1180.

Santos, B. S. (2007). Renovar a teoria crítica e reinventar a emancipação social. São Paulo: Boitempo.

Santos, B. S. (2009). Para além do pensamento abissal: das linhas globais a uma ecologia de saberes. In B. S. Santos \& M. P. Meneses (Eds.), Epistemologias do Sul (pp. 23-71). Coimbra: Ediçóes Almedina.

Santos, B. S. (2010). A gramática do tempo: para uma nova cultura política. São Paulo: Cortez.

Santos, B. S., \& Meneses, M. P. (2009). Introdução. In B. S. Santos \& M. P. Meneses (Eds.), Epistemologias do Sul (pp. 9-19). Coimbra: Ediçôes Almedina.

Singer, P. (2003). Economia solidária. In A. D. Cattani (Ed.), A outra economia (pp. 116-125). Porto Alegre: Veraz Editores.

\section{Funding Source}

CAPES.

\section{Corresponding author}

Isabela Aparecida de Oliveira Lussi

e-mail: bellussi@ufscar.br 